\title{
The Socialist Blues? Citizenship, Class and Civil Society.
}

What it means to be on the 'Left' today is currently the subject of considerable heated debate in the British context. After more than 10 years in office New Labour was finally defeated in the 2010 general election. Amongst the recriminations about the war in Iraq and concern about directions that were not taken what the 'Left' stands for is far from clear. Rising levels of inequality, progressive privatisation, the alliance with President Bush and the attack on civic freedoms left many without a secure compass. In one analysis the Left's historic project to tame capitalism has been defeated as the logic of the market has increasingly spread into the civil order. The decline in alternative institutions like trade unions and lack of alternative public spaces mean that British society is more market driven than ever before. However despite evidence of defeatism the idea of the Left is still evident in a diversity of publications including the Guardian newspaper, New Statesman and more academic New Left Review. In addition a diversity of web sites, journals (especially Soundings) and left learning think tanks like Compass, and others have all been actively involved in trying to rethink an alternative Left project after the end of new Labour. Further the election of Ed Miliband as Labour leader has begun the process of redefining the Labour Party. Unlike his more immediate predecessors Brown and Blair he has adopted a more traditional social democratic language and declared the New Labour project over. Further we might also add that the current Liberal and Conservative coalition cuts agenda has seen a dramatic increase in Left orientated politics against the attack on the public sector. This has involved the mobilisation of students, public sector workers and trade unionists as well more direct action by UK Uncut in an attempt to both politicise the failings of capitalism and the unfairness of public sector cuts.

Here I seek to recognise that there are indeed multiple ideas of the Left available within the British context. This ranges from the continuation of a number of complex traditions inspired by social democracy, more revolutionary ideas and of course the critical legacy of the New Left. We need to recognise that these diverse 
traditions are not only mutable over time, but also continue to be capable of reinventing themselves in different historical periods (Williams 1980). However in the context of this article I want to focus upon a set of debates that concentrate upon the relationship between the broader labour movement and the Labour Party. This is justified due to the historical relationship that has long existed between the two since the founding of the Labour party by the trade unions in 1906 and because much Left orientated debate is centrally concerned with the future direction of state orientated policy (Pelling 1978).

This said the larger sociological question I would like to face in this paper is what kinds of transformation are currently taking place within the public and civic realm, and whose voices, perspectives and understandings are taken account of within that process. Here I shall be critical of those who either assume that all public space is simply colonised by elites allowing little possibility for resistance and the idea that critical debate has been postmodernised through a plurality of political protests. If the first view is overly pessimistic disallowing the considerable possibilities that remain for more critical forms of citizenship, the second is overly optimistic neglecting to analyse the considerable power at the disposal of elites, capital and states in seeking to 'manage' public debate. Here we might remember that prominent figures in the post-war New Left like C.Wright Mills (1959) and E.P. Thompson (1980) have long warned about the power of political, economic and military elites to both manipulate citizens and to effectively shut down the possibilities for civic activism and protest. Critical sociology has a long and established interest in whether contemporary society has been able to preserve a viable civic sphere enabling a diversity of public projects and different forms of protest (Habermas 1985). Indeed the idea of civil society has attracted a considerable amount of debate within sociology as an important domain currently undergoing a multitude of transformations where it is becoming increasingly difficult to locate the political in a number of overlapping global, local and national civic spheres (Beck 2012). While not wishing to dispute the significance of these debates for the present I wish to limit my argument to the British national public sphere and in particular debates concerning the future, past and present of the Left.

Recently cultural sociologist Jeffrey Alexander (2010) has taken aim at those that argue political or civic activity can no longer be sustained through the state. He argues against some of the more pessimistic voices on the New Left suggest that civic intervention and action is still possible. Alexander (2010:117) writes that '[p]olitical 
struggles in contemporary societies are not determined by the power of social elites and state bureaucracies. They are deeply affected by moral ideas about citizenship and human rights. Between social power on the one side, and state power, there sits a cultural and institutional space that can be called the "civil sphere"'(Alexander 2010:117). This sphere is not only determined by an emphasis upon the ability to reason publicly and legal norms as in much liberal political philosophy, but also crucially for sociologists by more affective feelings, values and sentiments. Such a view emerges from Durkheim's (2001:341-343) well known critique of Kant where he both recognises the importance of law, rights and the public use of reason, but argues we also need to recognise the social world of values, feelings and social solidarity with others. Jeffrey Alexander (2006) has extended these insights by arguing that the key struggle within the context of a democracy is for a sense of social and cultural solidarity with others. A sociological understanding of civil society then will seek to understand the different ways in which civic codes and practices make divisions between the included and the excluded. Here we need to identify the key narratives and myths that give a sense to different political projects, and then seek to understand how they work within the civic sphere. We should also seek to recognise that while the civic realm is likely to be dominated by a plurality of narratives that it is the main task of social movements to aim at 'civic repair'. This is a form of cultural politics that aims to disrupt notions of the Other, and seek to make space for difference while correcting harmful stereotypes and degrading normalising understandings that deny a shared sense of humanity. Further the domain of civil society is not only symbolically constructed but more crucially involves the negotiation of questions of respect, voice and wider forms of democratic engagement. The question as to who is included and excluded within the narratives of civil society is sometimes called the politics of cultural citizenship (Stevenson 2003).

Within this setting I wish to focus upon ideas of social class in British Left debates. Within the British setting it has been the politics of equality and class, and the desire to repair 'the injuries' of a class ridden society that has proved to be the most powerful motivating force for labour politics (Sennett and Cobb 1973). However as we shall see there is little agreement within the broadly conceived domain of the Left about what these injuries are and then how we might come to repair them within the context of civil society. The inclusive fabric of society can be understood in a number of historically variable ways pointing towards differently understood and 
conceived Left projects and ideas. Here I want to investigate the shifting nature of these projects historically while also subjecting them to the more normative understandings informed through an understanding of critical sociology.

\section{Citizenship and the British Left}

Historically the main achievement of social democracy has been the development of a form of social citizenship that aimed to include a previously excluded working-class population (Bauman 2007, Moschonas 2002, Sassoon 1996). T.H.Marshall (1950) is credited as offering the main philosophical underpinning of the idea of social citizenship through his discussion of equal civil, political and social rights. However, as Marshall recognised, the normative achievements of citizenship based upon the principle of equality, were permanently threatened by the continuation of the class structure. Indeed for many on the post-war New Left the era of welfare capitalism was both a major achievement and yet did not go far enough given the only limited forms

of democracy that were allowed expression. This was especially apparent within what E.P.Thompson (1978a) and others thought was a narrowing of the public sphere in an age of welfare consensus. For Thompson as a prominent figure within the New Left social welfarism meant both a significant advance from the politics of the 1930s and a politics of retreat from questions concerning the nature of the good society and more civic forms of activism. Notably Marshall's analysis left most citizen's relatively powerless in the evolution and definition of rights while many New Left orientated commentators argued for more participatory definitions of citizenship. During the 1960s many on the Left continued to dream of a more autonomous and democratic society beyond capitalism. Reviewing this period, Cornelius Castoriadis (1997) argued that the Left is currently in retreat as socialists have almost entirely abandoned a critique of representative democracy and a systematic analysis of the supposed rationality of capitalism. For Castoriadis the Left is currently in danger of giving up on the project to radically transform and democratise society. A genuinely democratic society must be continually asking itself questions related to justice, equality and instituting the possibility of a self-critical life for its citizens. The principle concern amongst many on the New Left was that the age of welfare compromise did little to include the voices, perspectives and representations of the working-class majority who existed for the most part outside of the corridors of power and authority. 
For the Left equality, freedom and community go together as they have historically been motivated to find an alternative to the massive social divisions created by unregulated capitalism (Bobbio 1996). If the Left has not been exclusively concerned with class relationships it has historically sought to struggle for a society where capitalism did not dominate. As Geoff Eley (2002) argues this search since the 1850s has involved ideas of citizenship that preferred a society built on co-operation rather than competition and where a genuine democracy could only take root if the power of private property was regulated. In the European setting the Left were to progressively abandon a revolutionary model of social change for one that sought to utilise state power to follow egalitarian ends. Instead of seeking to replace society with the state the Left sought to connect an egalitarian society with a deeper model of democracy. However in terms of class politics there are considerable differences between social democrats like Tony Judt (2010) who simply bemoan the erosion of social citizenship and others on the New Left like E.P.Thompson (1970a) who persistently argued that the social democratic compromise between capital and labour had done little to extend more popular forms of democracy. However, as Geoff Eley (2002) argues, if the socialist politics after the second world war was built upon the labour or working-class movement this began to falter after the 1970s as it recognised that the old industrial working-class was in decline. This was not a society where class did not matter, but where the fragmentation of identities, the rise of the New Right and the decline of class solidarities plunged the Left into a long crisis. As Eley argues it was the decline of organised labour after the labour defeats of the 1980s that has precipated a prolonged identity crisis within the Left. This crisis gave rise to a new generation of thinkers connected with the idea of New Times who sought to reinvent an idea of the Left without the idea of a homogeneous working-class to call upon (Hall and Jacques 1983). If the working-class were always more variable than the mythology allowed undoubtedly its presence gave the idea of the Left coherence it would otherwise lack. Along with the decline of the labour movement and with that the idea of a Labour party rooted in working-class communities the idea of a Left project began to struggle. Raymond Williams (1980:249-250) as one of the most astute thinkers on the British New Left recognised that since 1973 not only had the working-class movement become increasingly 'incorporated' into the system it was meant to transform, but that the impact of unemployment and the defeat of trade 
unions along with increasingly hostility of the Labour Party to the labour movement suggested a growing sense of crisis.

If the labour movement has gone into decline this does not mean that the politics of class does not remain as powerful as ever. The historian Perry Anderson (1992:30) argues that the power structure of English society is dominated by an elite whose authority rests as much on wealth as it does on culture. Anderson described the English society in the 1960s as drenched in the codes of social-class and hierarchy that limited upward mobility while instilling a largely deferential pattern of social relationships. While E.P.Thompson (1978b) argued Anderson's views lacked a sense of continued working-class agency he would have concurred with the largely authoritarian nature of British class society. The class ridden nature of British society is such that even Conservative cultural commentators like Ferdinand Mount (2004: 107) admit that the decline in deference and class privilege has been considerably overstated as 'the adulation of the rich and famous is surely as fulsome as ever'. Indeed since the development of neoliberalism and the Thatcher government of the 1980s there has arisen a new generation of sociologists seeking to point to the injuries and civic harm of a pervasive class society. The important work of Mike Savage (1992), Beverley Skeggs (2004), Valerie Walkerdine (1990) and others have all sought to locate the different ways in which class hierarchies, assumptions and exclusions all remain part of everyday life in the British context. Beverley Skeggs (2004:57) has emphasised how neoliberalism has converted the notion of the middleclass citizen into a 'moral perogative'. The neoliberal self as the self-choosing and self-managed self produces the working-class Other as tasteless, unruly and generally lacking in cultural capital. Indeed the levels of inequality fostered by neoliberalism more generally undermine notions of collective solidarity help foster a sense of civic harm. In this respect, Richard Wilkinson (2006) argues that the levels of inequality promoted by neoliberal social policies undermine the common life of the community promoting increasingly individualistic forms of competition. Increasing competition for status, employment, houses and consumer goods promotes a stressful society where many people feel vulnerable to being considered inferior. If social integration is good for citizen's sense of well-being then competitive individualistic market cultures helps promote a sense of being a disrespected second-class citizenship. A lack of status leads not only to poor personal health but also to a general lack of selfworth and confidence more generally. Further class-divided societies promote feelings 
of superiority and self-satisfied privilege amongst the better off. These divisions then have helped promote new forms of class hatred often most visible through the distaste and hate speech directed at celebrities and others who are seen as lacking the appropriate social capital (Tyler and Bennett 2010).

Pierre Bourdieu (2002) argues that neoliberalism explicitly promotes a sense of insecurity and precariousness amongst working-class populations that impresses divisions between cosmopolitan elites and a more locally defined population who sometimes express their resentment through populist nationalism and racism. Here we also need to recognise that the composition of the working-class has changed increasingly divided between the skilled, the insecure and the unemployed. As Guy Standing (2011) has argued the 'precariat' can be defined as a group without a secure footing in the labour market and whose lives are blighted by short-term contracts, low wages and chronic levels of insecurity. Neoliberalism then through hostility to the social state, trade unions, financial regulation and the promotion of casualised labour, work fare and increased numbers of citizens in the prison population is profoundly hostile to the historical values of the Left in most of its guises (Harvey 2000, Wacquant 2010). These features also suggest then that class politics is far from redundant in the British context.

\section{Citizenship and the Long Revolution}

The idea of the Left then is that democracy, community and the struggle for equality are intrinsically connected. Here I shall argue it was certain sections of the New Left rather than the progressive statism of social democrats or revolutionary 'big bang' solutions who offered the best model of civic repair and civic engagement. Here we should perhaps recall the idea of the long revolution offered by Raymond Williams (1962) in the early 1960s and later refined throughout his later work. The long revolution was the historical struggle for a learning and communicative civil society. This was permanently held in check by both capitalism and the state that sought to convert the population into the identities of consumers, deferential workers and passive spectators. For Williams (1962:10) the democratic revolution could be said to be 'at an early stage' whose extension depended upon the recovery of the principles of self-management and autonomy. The idea of the long revolution meant that this would inevitably take time but was largely dependent upon the working-class 
movement pressing for a society where the value of democracy was as much a part of economic life as it was within political and cultural institutions. In terms of the public sphere civic repair for the subordinate working-class population could only come about in a radically transformed society where the values of capitalism had become subordinate to more democratic, learning and deliberative forms of citizenship.

Raymond Williams (1958:305) famously argued a democratic culture should seek to reaffirm an 'equality of being'. This means that democrats should seek to build human relationships through reciprocal forms of communication rather than domination. A socialist democracy should have at its heart a shared capacity to be able to build complex relations of communication that promote an authentic politics of voice, solidarity and responsibility. Later Williams (1983a:73-75) identified that the major impediment to the achievement of a complex learning and communicative democracy as the continuation of class hierarchy. This was maintained largely through the persistence of a ruling class or privileged group that protested against the development of meaningful forms of citizenship to those who were seen to be part of the 'lower' orders. Privileged groups would find reasons why extensions of democracy, education and culture could not really be made outside of elite circles. Second Williams argues that elite groups often manage to find members of the working-class who having experienced some class mobility to speak of the vulgarity of the lower orders. Noteably in these changing times much 'reality television' is explicitly concerned with the inability of the poor to live responsibly. Instead of relying upon the state much 'reality television' seeks to educate the audience into becoming self-reliant enterprising selves concerned with upward mobility (Ouellette and Hay 2008). Finally crude ideas of ordinary people as 'the masses' persists into the present and can be connected to elitist assumptions that inevitably rest upon ideas about different social classes. This is mostly evident through the popular use of the term 'chav'. As Owen Jones (2011) has pointed out the demonisation of workingclass people along with ideas of welfare dependency, shameless lifestyles and tastelessness has meant that the poor have become the new enemy within British society. The most vulnerable sections of society who had once won the protection of trade unions and the welfare state are now the daily object of cruelty and class baiting. If when Williams was writing many working-class people were able to take pride in themselves due to the achievements of the labour movement this it would seem is no longer the case given the impact of neoliberalism. If the Left is indeed to have a future 
it needs to be able to speak of the possibility of a dignified future for all of its citizens and of the kinds of structural transformation that are necessary if we are to live up to the principles of equality, community and democracy. The term 'chav' is not simply problematic as a form of prejudice, but what it indicates about the wider set of social relations where many working-class people are unable to live lives of dignity, inclusion and purpose. The partial collapse and defeat of the labour movement after Thatcherism has left many citizens vulnerable to the demands of capitalism, welfare to work and the most punishing of stereotypes built upon class hatred. However, as I indicated earlier, this political transformation would not seem to be structurally possible without the active and critical revival of the working-class and labour movement. Without social movements seeking to 'repair' the civic injuries inflicted upon the working-class by neoliberalism it is not clear how a more social just and less injurious society in respect of class relationships could emerge.

\section{New Labour, The Third Way and the Politics of Class}

The rise of the New Right, the arrival of a more globalised world and the long term decline of the labour movement meant that when the New Labour government were elected in 1997 a different kind of political ideology was required to help foster a sense of political legitimacy. All political and social movements need to invent sets of stories and narratives that connect with citizens and voters outside and inside the organisational structure (Alexander 2011). The New Labour government aimed to do this by calling on one of Britain's leading sociologists Anthony Giddens and his notion of the third way. The idea of the third way was meant to provide an alternative to both old style social democracy that was both overly bureaucratic and too focused upon rights rather than responsibilities, and neoliberalism which emphasises privatisation, inequality and free market competition. It is therefore false to brand the third way as many on the revolutionary Left have tried to as neoliberalism in disguise, as it belongs to the histories and traditions of social democracy (Callinicos 2001). Antony Giddens (1998) sought to refashion social democracy for an age where class division was no longer experienced by many citizens as the central fault line governing politics. For Giddens (1998:64) third way politics should take a 'positive attitude towards globalisation' while recognising the decline in Left/Right polarity, increasing fragmentation and life-style diversity and the progressive development of 
new political voices outside of more conventional class politics. Third way citizenship would need to press the idea of 'no rights without responsibilities' and develop a new politics where tradition was losing its force in the face of increasingly life-style reflexivity (Giddens 1998:65). The third way also proposed considerable constitutional reform that aimed at the 'democratising of democracy', and the attempt to bring in more agencies from within civil society in order to help devolve power down to citizens (Giddens 1998:72). The main aim however was to provide a model for the inclusive society that was particularly concerned about a growing underclass who were increasingly cut off from mainstream society. Here then there was an attempt to address questions of civic repair and to promote a common citizenship orientated around public service reform and a welfare state that benefits everyone.

The problem for many like Stuart Hall (2003) and Chantel Mouffe (2005) who had long associations with the New Left was that the pro-market and pro-globalisation stand of the third way had little to say about the increasing dominance of the economic system over social and cultural life more generally. Here concern was raised about the consequences of privatising the welfare state, the lack of concern about levels of inequality and the absence of a critical language concerning markets and capitalism more generally. Further other critics like Jurgen Habermas (1999) were concerned about the attempts by the state to instil pro-market identities so as to foster 'positive' lifestyles in respect of the global market. To put the point more forcibly Beverley Skeggs (2004) argued that talk of reflexive modernity, globalisation and exclusion had erased the more critical language of capitalism, inequality and domination that should occupy the centre ground of political analysis. Within third way rhetoric the 'underclass' were often seen as exhibiting a culture of dependency thereby blaming and scapegoating them for their own plight. Skeggs argues that the third way rests upon the symbolic power of the middle class more generally who were keen to distance themselves from poor working-class people.

Of course in practice the New Labour government achieved some redistribution and over saw a period that might be thought of as a period of increasing inequality, but falling poverty. Here New Labour saw rising taxes for the well off as 'anti-aspirational' but raised enough revenue through so called stealth taxes to protect unemployed people with children and the elderly reliant on state benefits (Gregg 2011). New Labour did not ever effectively challenge the neoliberal model, but did manage to preserve a social democratic face enabling them to address some of the 
harsher aspects of neoliberal doctrine. However in terms of a wider politics of civil society there was little attempt to address the broader culture of decline in respect of the broader labour movement, and little attempt by trade unions to promote civic identities that focused upon longer term historical memories and broader cultural questions.

In practice the most often used metaphor by New Labour was the idea of modernisation not the third way. Here there was a considerable amount of emphasis placed upon progressive modernisers who were seeking to adapt to a new technologically defined global economy and so called conservatives who were opposed to change. Alan Finlayson (2003) argues in this respect there was a lack of concern to locate civic identities in the context of power and inequality with the charge of conservativism often being levelled at the labour movement for not keeping pace with the times. New Labour here failed to offer an ideological alternative to Thatcherism that overwhelming addressed the public as consumers rather than as potential democratic citizens. Similar features could also be detected within the internal culture of the Labour Party where policy was largely formulated by elites (including think tanks and professional politicians) and public sector reform was pursued through the use of hierarchically conceived targets. New Labour in this respect sought to develop a market driven society that kept a tight control over the mechanism for making policy and reforming the public sector (Faucher-King and Le Gales 2010). Absent from these debates was any attempt to build wider civic relationships within the labour movement that might help resist and reform capitalism or indeed act as a meaningful participant within debates. Indeed if the argument stopped here we might assume that the pessimists are correct and that organised labour and working-class people more generally have been effectively shut out of conversations in respect of politics and the Left. However, as we shall see, after the third way, there has been a renewed attempt to rethink the idea of the labour movement through the emergence of a group that has been called Blue Labour. 


\section{Blue Labour: A Case of Left Melancholia?}

After New Labour there have emerged a number of competing groups all seeking to offer the Labour Party and movement a new narrative and sense of identity. Some of these have sought to hold onto the 'achievements' of the Third Way, but by far the most interesting in terms of a politics of civic repair and civil society are a political grouping often referred to as Blue Labour. While it is difficult to know how influential this group will go onto to be in influencing the Left policy debates of the future they have already excited a considerable amount of debate within the Left orientated public sphere I mentioned in the introduction. The journalist Rowenna Davis's (2011) book length exploration of Blue Labour has identified three ethical strands to this political formation that marks it out as distinctive to the Third Way. First the engagement with the broader interests of civil society needs to stretch beyond professionally organised policy groups and should also include groups like the English Defence League (EDL) often assumed to beyond the boundaries of liberal democratic politics. This is not because Blue Labour are overtly racist but because a strong value is placed upon the idea of national community and a politics of place all of which are shared by the EDL. Secondly there is a strong commitment to strengthen the relational fabric of civil society through families, religious groups and self-help organisations as a means of offering an alternative politics to a technocratic state. Here Blue Labour come close to some of the social capital debates around community encouraged by the Third Way, but this time there is a concern that the Labour Party could do more to improve its own relationship with the wider community (Putnam 2000). Finally there is a desire to adopt a different model of political economy from New Labour away from the finance capital of New Labour into a stronger support for local businesses, co-operatives and mutuals, worker representation on boards, the living wage and other features.

The key public moment that led to the formation of Blue Labour is what is sometimes called 'Bigotgate' or the 'Maureen Duffy affair'. This was a moment during the 2010 general election where the concerns of a working-class and Labour activist on questions of immigration where dismissed in an insulting fashion by the then Labour leader Gordon Brown. For Blue Labour this emphasised not only the 'out 
of touch' nature of New Labour, but also the way they dealt with issues raised by citizens outside of policy elites.

The key intellectual in the formation of Blue Labour is Maurice Glasman (2011a) who has recently been made a Lord by Labour leader Ed Miliband. For Glasman the labour movement's political traditions are in part conservative and based upon the need to place limits on the market in favour of the common good. Glasman argues that the real problem became after the famous Labour victory of 1945 was the political technocrats came to dominate debate as the society built upon equal rights became a state driven discourse from above. As the labour movement went into decline the idea of a society based upon equal rights was driven more by the state than active members of civil society. More specifically Glasman (2011a) argues that this top down state centred version of socialism found its main theoretician in Anthony Crossland. It was Crossland's (1956) version of socialism that prioritised state driven attempts to guarantee certain rights to welfare while neglecting the development of socialism based upon mutual aid, reciprocity and decent human relationships. State driven socialism favoured scientific management, state control and planning from above. The problem is that an agenda driven by technocratic rights has dominated socialist agendas rather than a more ethical politics of the common good, mutuality and self-help.

If the labour movement began with the aim of civilising capitalism through the need to develop co-operatives, unions and societies built upon common concern then currently it is more driven by bureaucratic targets and policy wonks. The idea of Blue Labour seeks to develop a common politics of citizenship that resists recent debates about postmodern plurality, but instead seeks to develop a programme based upon common interests located in family, faith and patriotism. Glasman (2011a) seeks to reclaim the labour movement as the movement less concerned with league tables and targets but more rooted in campaigns for a living wage, affordable housing and the resistance to the privatisation of the commons.

Maurice Glasman (2011b) has more recently called for a return to apprenticeships for working class people so that they are able to gain a sense of pride and belonging through their labour. Here Glasman's argument takes a Durkheimian turn through his belief in professional and collective associations that are independent from the state and market that can grant working people a sense of moral dignity. For Glasman and Durkheim socialism is based upon a morally regulated economy 
supported through a shared sense of the duty of labour. Both Glasman and Durkheim share an admiration for the traditions of guild socialism as offering an alternative to bureaucratic versions of socialism like those proposed by the Fabian society. As Durkheim (1996:7) argues these associations can provide the conditions for the 'closer and frequent contact of individuals' to create the sociological conditions for a shared moral sense. These civil organisations along with an emphasis upon family, religion and nationalism are all important in the Blue Labour argument for establishing social solidarity (Glasman 2011c).

Similarly Jonathan Rutherford (2011) emphasises not only inequality, but the break-down of community, the rise of mental illness and an increasing sense of isolation and fragmentation in society. Here the Left must avoid simply rejecting current Prime Minister David Cameron's idea of the Big Society. The call for a more 'pro-social' society built upon mutual relations by Cameron is something that those arguing for the labour movement to be re-built should support. Historically Labour in power stand accused of an authoritarian managerialism and of neglecting to remake public institutions through more humane and democratic relationships. Maurice Glasman (2010) has also argue that a left version of the Big Society needs to emphasis more active civic undertakings as opposed to the consumerism of New Labour but argue the scope to volunteer is narrowed in a class society built upon low wages at the bottom and irresponsibile capitalism at the top.

Elsewhere Labour MP John Cruddas and Jonathan Rutherford (2010) have sought to redefine ethical socialism as coming out of an attempt to relink the common good and social relationships that give meaning to people's lives. Ethical socialism recognises the interdependency of our lives and 'the social connections between individuals, which shape both our psyche and our place in the order of things' (Cruddas and Rutherford 2010:17). While the idea of Blue Labour is likely to have a number of inflections it is essentially an attempt to reinvent a life in common that is being destroyed by state imperatives, capitalism and other instrumental measures that erode human relationships based upon the idea of the common good. This agenda might be more broadly described as a form of Left communitarianism that explicitly seeks to remake ideas of community from the bottom up. The civic repair offered by Blue Labour seeks to instill a sense of pride within working-class communities by reviving the labour movement and the traditions of self-help from the past. Within this respect, like the New Left they seek to reintroduce a sense of popular agency from 
below notably missing in the more statist agenda pursued by New Labour. Rather than simply voting Labour and then hoping for the best, Blue Labour and the New Left sought to develop the civic capacity of ordinary citizens. The difference being that for many on the New Left the break with class elitism required a radical democratic transformation of society whereas the Blue Labour project seems to be less concerned with a critique of class hierarchy than it is with the erosion of community and reciprocity.

Here there has been a concern that Blue Labour does seem to have a nostalgic relationship to the past and looks back at a world before the age of cultural pluralism and more global levels of mobility. This reading seems to be particularly evident in the need to reinvent the labour movement after its apparent demise. Indeed it has reported that the charge of nostalgia has been levelled at Blue Labour by former leader of New Labour Tony Blair (Riddell 2011).It is in this setting I would like to address Wendy Brown's $(2003,2005)$ arguments about the limits of Left melancholia. Brown has correctly identified neoliberalism as a political force that aims to destroy all forms of opposition to capitalist rationality. She argues that democratic, religious and ethical values are all increasingly being subjected to cost-benefit forms of economic calculation. In this context ideas of liberal democracy are themselves being eroded and pose serious questions as to how to do criticism in the context of the present. At this point Brown is critical of a Left that seems to cling to the values of liberal democracy after its passing. In this context, Brown (2005: 54-55) argues that 'loss can take shape as melancholic, including the straight forward possibilities of idealizing a lost object as it was never idealized when it was alive'. While the Left defends civil rights, neoliberalism makes over the social and cultural world in terms of market values and economic forms of calculation. Here Brown (2005:57) comments that the 'space between liberal democratic ideals and lived realities has ceased to be exploitable, because liberal democracy itself is no longer the most sentient discourse of political legitimacy and the good life'. There is she reasons little point in complaining about anti-democratic measures if the dominant hegemony is that of economic calculation. Wendy Brown (2005: 59) points to the possible future formation of a Left position that rejects the corporate citizen in favour of a vision that explores the possibility of social justice, ecological vulnerability and the possibility of living an ethical life. 
Of course any attempt to translate Brown's remarks into the British context is difficult given the different ways in which historically citizenship has taken root (Birnbaum 2001). However if we could at one time have separated British social citizenship from the liberal citizenship of the United States this is now increasingly problematic. The class struggles of the early 1980s during the first wave of neoliberalism undermined British social citizenship and this project is now being returned to by the newly elected coalition between the Liberals and Conservatives. However despite a shared history of social liberalism in Europe and the United States the later remains more market driven than most European societies. The historian Michael Mann (1987) has argued that if the class conflicts of the British working class were absorbed into a post-war social citizenship this remains distinct from the liberal citizenship that dominated the United States. After the rise of neoliberalism, British citizenship is increasingly emphasising ideas of dependency culture, charitable giving and the down grading of state provision more generally that is characteristic of more liberal ideals. For Brown the inability of the Left to mourn the passing of previous forms of critique has been central to its ambivalence towards postmodernism and identity politics more generally. Brown suggests that if the Left loses a future orientated emancipatory vision it will only be a limited force in the future. Here the argument is not for the Left to eject its core values of equality, dignity and freedom but instead to articulate these principles in terms of a more positive vision.

Wendy Brown's concerns are built through an engagement with Walter Benjamin's (1931) and Freud's (1984) ideas about mourning and melancholia. This becomes translated by Brown as the inability by the Left to mourn lost projects and connect with more contemporary realities. Brown (2006) recognises the need to 'fuse' a number of different democratic projects that could indeed give us a sense of hope for the future. Perhaps returning to Freud (1984:260) what becomes apparent is that the experience of 'loss' can be a space of ambivalence and perhaps even renewal. While Wendy Brown is writing in the American context her comments are suggestive of some of the problems faced by the British Left. Blue Labour politically have sought to re-emphasise the importance of tradition, and sometimes sound as though they would like to return a less insecure world before the development of globalisation and neoliberalism. However nostalgia is capable of both being a force for emancipation or a justification of more oppressive relationships depending upon the context. Blue Labour in this setting retains at least two key insights. The first of 
which is the need to rebuild the labour movement from the bottom up in an attempt to place restraints upon the operation of capitalism. Despite the importance of a politics of diversity and difference there is no substitute for labour organisations that place limits on the further development of capitalism. Secondly the idea of Blue Labour recognises the violence done to human relationships if everyday life becomes progressively about the balance sheet, utilitarianism and questions of profit and loss. Here there is an attempt to recapture a common ethical language that recognises the value of tradition.

Instead the charge I would place at Blue Labour's door is less nostalgia but its neglect of questions related to freedom, power, democracy and liberty. Notably Anthony Crossland (1956/2006:405) who is dismissed as a statist carefully defended the virtues of freedom, liberty and dissent in a way that is currently missing from the Blue Labour debate. Further, we saw earlier, how entrenched class relationships and an emphasis upon hierarchy prevented citizens from becoming critical citizens. Raymond Williams (1962) remains a key figure in this respect. Missing from Blue Labour's thinking at this point in their development is a more concerted attempt to talk not only about tradition, but also about the creation of more democratic and critical spaces where tradition can be questioned and challenged. The model of civil society offered in this respect while suggesting an alternative to the relentless top down modernism of New Labour does not do enough to foster more liberal and critical values like tolerance and criticism.

\section{Citizenship and the Civic Realm}

This article has sought to demonstrate that despite fears that the civil society is being colonised by the state and the power of capital that the arena of labour politics has demonstrated itself as capable of being reinvented over the recent period. This does not however necessarily dismiss more pessimistic claims about the decline of a more activist and engaged citizenship, but it does point to the idea the idea that state driven political parties require an active relationship with civil society if they are to renew themselves. We saw how in respect of class politics both social democracy and the New Left had different understandings of a politics of civic repair, and how the third way sought to develop a different kind of politics in the face of the decline of the labour movement. While the lessons of the Third Way are many the one I have sought 
to emphasise here is the inadequacy of its response to neoliberalism can in part be understood less through the language of betrayal, but more through the decline of the organised working class that has traditionally supplied the Left with a strong sense of cultural identity. Blue Labour in this regard seeks to return the labour movement to the centre of the civil sphere refusing to mourn the passing of a labour movement that might once again become a source of critique and civic identity. Such features as we have seen are an attempt to 'repair' the damage done by the Third Way and its neglect of class and social relationships more generally. Blue Labour in this regard represents an attempt to wrestle power from more professional orientated think tanks within the Labour Party. However since Max Weber (1948) we also need to recognise that political parties continue to rely upon administrative experts, charismatic leaders and the battle for power. In other words, while critical elements within the labour movement have sought to democratise power (here there is a clear link between the New Left and Blue Labour) such features also need to include an appreciation of the limits involved in this particular strategy. Indeed it is not clear yet whether Blue Labour themselves are simply another intellectual clique who will disappear just as quickly as they appeared should Labour lose the next election. This is not to agree with those who argue that we live in a post-democratic society, but it is to suggest that the power of the media, the growth in the power of capital and the decline of the labour movement all have implications for the civic context of politics (Crouch 2004).

If the aim of labour politics is a politics of civic repair in respect of the broader public realm this however can-not be effectively pursued without a recognition of more liberal and critical traditions (Bronner 2004, Diamond and Kenny 2011). If the homogenous working-class are indeed part of an imaginary in decline then a critical politics that aims to address the injuries of working class people in the attempt to build a more equal, community orientated and democratic society becomes a difficult achievement. Here my concern was that if New Labour remains overly distant from a more critical language of capitalism then Blue Labour have been right to suggest that the wider labour movement is in need of reconstruction. However what is far from clear is whether a politics focused around work, tradition, family and the flag will be able to give expression to the increasingly diverse place that Britain has become since the first 'proper' Labour government of 1945. 


\section{Bibliography}

Alexander, J.C. (2006) The Civil Sphere, Oxford, Oxford University Press.

Alexander, J.C. (2010) 'Power, Politics, and the Civil Sphere', in Leicht, K.T. and Jenkins, J.C. (eds) Handbook of Politics: State and Society in Global Perspective, New York, Springer Science/Business Media pp111-126.

Alexander, J.C. (2011) Performance and Power, Cambridge, Polity Press.

Anderson, P. (1992) English Questions, London, Verso.

Bauman, Z. (2007) 'Has the future a Left?' Soundings: A journal of culture and politics, Issue 35 Spring 2007 pp8-15.

Beck, U. (2012) Twenty Observations on a World in Turmoil, Cambridge, Polity Press.

Benjamin, W. (1931) 'Left-Wing Melancholy', Walter Benjamin: Gesammelete Schriften, vol 3 pp279-83.

Birnbaum, N. (2001) After Progress, Oxford, Oxford University Press.

Bobbio, N. (1996) Left and Right, Cambridge, Polity Press.

Bourdieu, P. (2003) Firing Back: Against the Tyranny of the Market 2, London, Verso.

Bronner, S.E. (2004) Reclaiming the Enlightenment, New York, Columbia Press.

Brown, W. (2003) 'Resisting Left Melancholia', in Eng, D.L. and Kazanjian, D. (eds) Loss: The Politics of Mourning, Berkeley, University of California Press. 
Brown, W. (2005) Edgework: Critical Essays on Knowledge and Politics, Princeton, Princeton and Oxford University Press.

Brown, W. et al (2006) 'Learning to Love Again: An Interview with Wendy Brown', Contretemps 6, January 2006.

Callininicos, A. (2001) Against the Third Way, Cambridge, Polity Press.

Castoriadis, C. (1997) 'The Retreat from Autonomy: Postmodernism as Generalized Conformism', World in Fragments, Stanford, Stanford University Press pp32-46.

Crouch, C. (2004) Post-Democracy, Cambridge, Polity Press.

Crossland, R. (1956/2006) The Future of Socialism, London, Constable.

Cruddas, J. and Rutherford, J. (2010) 'Ethical socialism', Soundings: A journal of politics and culture $44 \mathrm{pp} 10-21$.

Davis, R. (2011) Tangled Up in Blue: Blue Labour and the Struggle for Labour's Soul, London, Ruskin Publishing.

Diamond, P. and Kenny,M. (2011) 'Introduction', in Diamond, P. and Kenny, M. (eds) Reassessing New Labour, Oxford, Wiley-Blackwell pp4-15.

Durkheim, E. (1996) Professional Ethics and Civic Moral Codes, London, Routledge. Eley, G. (2002) Forging Democracy: The History of the Left in Europe 1850-2000, Oxford, Oxford University Press.

Finlayson, A. (2003) Making Sense of New Labour, London, Lawerence and Wishart. Freud, S. (1984) 'Mourning and Melancholia', On Metapschology, London, Pelican pp245-268.

Foucher-King, F. and Le Gale, P. (2010) The New Labour Experiment, Stanford, Stanford University Press.

Glasman, M. (2010) 'Society not State: The Challenge of the Big Society’, Public Policy Research, June/August 2010 pp59-63.

Glasman, M. (2011a) 'Labour as a radical tradition', Soundings 46 accessed on line at www.lwbooks.co.uk 1 June 20011

Glasman, M. (2011b) Talk given to Nottingham Fabian Society (based on authors notes), October 2011.

Glasman, M. (2011c) 'My Blue Labour vision', The Observer newspaper pp 24-25.

Gregg, P. (2011) 'New Labour and Inequality', in Diamond, P. and Kenny, M. (eds)

Reassessing New Labour, Oxford, Wiley-Blackwell pp16-30.

Habermas, J. (1985) The Philosophical Discourse of Modernity, Cambridge, Polity Press. 
Habermas, J. (1999) 'The European nation-state and the pressures of globalisation', New Left Review 235 (May/June) pp1-12.

Hall, S. and Jacques, M. (1983) (eds) The Politics of Thatcherism, London, Lawerence and Wishart.

Hall, S. (2003) 'New Labour's double-shuffle', Soundings 24:10-24.

Harvey, D. (2000) The New Imperialism, Oxford, Oxford University Press.

Jones, O. (2011) Chavs: The Demonisation of the Working Class, London, Verso.

Judt, T. (2010) Ill Fares the Land, London, Allen Lane.

Mann, M, (1987) 'Ruling Class Strategies and Citizenship', Sociology 21 (3) pp339354.

Moschonas, G. (2002) In the Name of Social Democracy, London, Verso.

Mouffe, C. (2005) On the Political, London, Routledge.

Mount, F. (2004) Mind the Gap, London, Short Books.

Marshall, T.H. (1950) Citizenship, Social Class and Other essays, Cambridge, Cambridge University Press.

Ouellette, L. and Hay, J. (2008) Better Living Through Reality TV, Oxford, Blackwell.

Pelling, H. (1978) A Short History of the Labour Party, London, MacMillan.

Putnam, R. (2000) Bowling Alone, New York, Touchstone Books.

Riddell, M. (2011) 'Way to Blue: The Fabian Interview Maurice Glasman', Fabian

Review, Summer 2011 pp7-9.

Rutherford, J. (2011) 'Labour's good society', Soundings 46 accessed on line at www.lwbooks.co.uk 1 June 20011

Savage, M. et al (1992) Property, Beaucracy and Culture, ref...

Sassoon, D. (1996) One Hundred Years of Socialism: The West European Left in the Twenthieth Century, London, I.B.Tauris.

Sennett, R. and Cobb, J. (1973) The Hidden Injuries of Class, New York, Vintage Books.

Skeggs, B. (2004) Class, Self, Culture, London, Routledge.

Standing, G. (2011) The Precariat: The New Dangerous Class, New York, Bloomberg Academic.

Stevenson, N. (2003) Cultural Citizenship, Open University Press.

Thompson, E.P. (1980) Writing by Candelight, London, Merlin. 
Thompson, E.P. (1978a) 'Outside the Whale', The Poverty of Theory and Other Essays, London, Merlin pp 1-34.

Thompson, E.P. (1978b) 'The Peculiarities of the English', The Poverty of Theory, London, Merlin pp 35-91.

Tyler, I. and Bennett, B. (2010) 'Celebrity chav: Fame, feminity and social class', European Journal of Cultural Studies13(3) pp375-393.

Wacquant, L. (2010) 'Crafting the Neoliberal State: Workfare, Prisonfare, and Social Insecurity', Sociological Forum 25(2) pp197-220.

Walkerdine, V. (1990) Schoolgirl Fictions, London, Verso.

Weber, M. (1948) 'Politics as Vocation', in Gerth, H. and Wright Mills, C. (ed) From Max Weber: Essays in Sociology, London, Routledge and Kegan Paul Ltd pp77-128.

Wilkinson, K. (2006) 'The impact of inequality’, Social Research 73(2) pp711-732.

Williams, R. (1958) Culture and Society, London, Pelican.

Williams, R. (1962) The Long Revolution, London, Pelican.

Williams, R. (1980) 'Notes on Marxism in Britain Since 1945', Culture and

Materialism, London, Verso pp233-252.

Williams, R. (1983) Towards 2000, London, Pelican.

Wright Mills, C.W. (1959) The Power Elite, Oxford, Oxford University Press. 